\title{
DISTRIBUSI ALIRAN BERBAGAI BENTUK DRAG MODEL DENGAN VARIASI KECEPATAN FLUIDA MENGGUNAKAN SOFTWARE FLUENT FLOWIZARD 2.0.4
}

\author{
Gigih Dwi Nugroho, F.A Widiharsa", Moch. Ma'ruf \\ Jurusan Teknik Mesin, Fakultas Teknik, Universitas Merdeka Malang \\ *Email corresponding author: fransiskus.widiharsa@unmer.ac.id
}

\begin{abstract}
Abstrak
Fenomena aliran fluida melalui suatu bentuk body hambatan/drag model merupakan fenomena yang sering kita temui dalam kehidupan. Bentuk drag model yang berbeda akan menghasilkan karakteristik aliran fluida yang berbeda dan sangat berpengaruh terhadap fungsi dari bentuk drag model tersebut. Fluent Flowizard adalah software dengan program Computational Fluid Dynamics (CFD) yang dapat mensimulasikan aliran fluida pada sekitar permukaan desain berbagai macam bentuk drag model. Tujuan dari penelitian ini adalah untuk mengetahui distribusi tekanan statis dan tekanan total serta distribusi kecepatan berbagai bentuk drag model dengan variasi kecepatan aliran fluida. Drag model yang disimulasikan adalah bentuk bola, setengah bola cekung, setengah bola cembung, piringan dan streamline. Kecepatan aliran fluida yang digunakan untuk simulasi adalah kecepatan $10 \mathrm{~m} / \mathrm{s}, 15 \mathrm{~m} / \mathrm{s}, 20 \mathrm{~m} / \mathrm{s}$ dan $25 \mathrm{~m} / \mathrm{s}$. Hasil dari simulasi menunjukkan bahwa tekanan statis tertinggi terjadi pada bentuk setengah bola cekung saat kecepatan aliran $25 \mathrm{~m} / \mathrm{s}$ dengan besar tekanan statisnya 451 pascal, tekanan total tertinggi terjadi pada bentuk piringan saat kecepatan aliran $25 \mathrm{~m} / \mathrm{s}$ dengan besar tekanan totalnya 475 pascal, dan peningkatan kecepatan tertinggi terjadi pada bentuk setengah bola cekung dan cembung pada kecepatan $25 \mathrm{~m} / \mathrm{s}$ dimana kecepatanya menjadi $28,8 \mathrm{~m} / \mathrm{s}$ atau meningkat 3,8 $\mathrm{m} / \mathrm{s}$ dari kecepatan awal.
\end{abstract}

Kata Kunci: Drag Model, Simulasi, Fluent Flowizard

\begin{abstract}
The phenomenon of fluid flow through a form of body resistanceldrag model is a phenomenon that we often encounter in life. Different drag models will produce different fluid flow characteristics and have an effect on the function of the drag shape of the model. Fluent Flowizard is software with Computational Fluid Dynamics (CFD) program that can simulate fluid flow around the design surface of various forms of drag models. The purpose of this research is to find out the static pressure distribution and total pressure and speed distribution of various drag model with variation of fluid flow velocity. The simulated model drag is a ball shape, half a concave ball, half a convex ball, a dish and a streamline. The fluid flow velocity used for the simulation is velocity of $10 \mathrm{~m} / \mathrm{s}, 15 \mathrm{~m} / \mathrm{s}, 20 \mathrm{~m} / \mathrm{s}$ and $25 \mathrm{~m} / \mathrm{s}$. The result of the simulation shows that the highest static pressure occurs in the half-sphere concave ball at flow velocity $25 \mathrm{~m} / \mathrm{s}$ with a static pressure of 451 pascal, the highest total pressure occurring in the disk shape at a flow velocity of $25 \mathrm{~m} / \mathrm{s}$ with a total pressure of 475 pascal, and the highest speed increase occurring in the concave and convex half ball at a speed of $25 \mathrm{~m} / \mathrm{s}$ where the speed becomes $28.8 \mathrm{~m} / \mathrm{s}$ or increases $3.8 \mathrm{~m} / \mathrm{s}$ from the initial speed.
\end{abstract}

Keywords : Drag Model, Simulation, Fluent Flowizard

\section{PENDAHULUAN}

\section{Latar Belakang}

Fenomena aliran fluida melalui suatu bentuk body hambatan/drag model merupakan fenomena yang sering kita temui dalam kehidupan. Bentuk drag model yang berbeda akan menghasilkan karakteristik aliran fluida yang berbeda dan sangat berpengaruh terhadap fungsi dari bentuk drag model tersebut. Dengan demikian pemilihan bentuk drag model untuk sebuah aplikasi tertentu harus sangat diperhatikan, kesalahan dalam pemilihan bentuk drag model dapat mengakibatkan kurang maksimalnyafungsi dari penggunaan tersebut. Untuk itu perlu diketahui karakteristik dari setiap bentuk drag model tersebut untuk bisa diaplikasikan sesuai dengan fungsinya.

Fluent Flowizard adalah software dengan program komputasi Computational Fluid Dynamics (CFD) yang dapat 
mensimulasikan aliran fluida pada sekitar permukaan desain berbagai macam bentuk drag model dengan dibantu oleh software design model (AutoCAD). Dengan software Fluent Flowizard ini bisa diketahui karakteristik aerodinamikadari berbagai macam bentuk drag model yang diujikan dengan variasi kecepatan aliran fluida sehingga bisa didapatkan peformansi maksimum dari suatu bentuk benda dengan kondisi tertentu.

\section{Tujuan Penelitian}

Tujuan dari penelitian ini adalah:

1. Mengetahui nilai dan distribusi tekanan statis pada permukaan berbagai bentuk drag model dengan variasi kecepatan aliran fluida.

2. Mengetahui nilai dan distribusi tekanan total pada permukaan berbagai bentuk drag model dengan variasi kecepatan aliran fluida.

3. Mengetahui nilai dan distribusi kecepatan pada permukaan berbagai bentuk drag model dengan variasi kecepatan aliran fluida.

\section{KAJIAN PUSTAKA}

\section{Aerodinamika}

Aerodinamika berasal dari dua buah kata yaitu aero yang berarti bagian dari udara dan dinamika yang berarti cabang ilmu alam yang menyelidiki benda-benda bergerak serta gayayang menggerakkan benda-benda tersebut. Pada intinya aerodinamika bertujuan untuk memecah kecepatan atau hambatan udara pada saat kecepatan tinggi. Hambatan udara yang bekerja pada suatu model hambatan terutama ditentukan oleh bentuk body dari model hambatan tersebut. Gaya aerodinamika pada suatu model hambatan memang terlihat sangat komplek, terlebih pada interaksi antara bentuk model hambatan, fluida, dan kecepatan aliran. Akan tetapi sebenarnya gaya dan momen aerodinamika pada model hambatan hanya disebabkan oleh dua sumber utama yaitu:

1. Distribusi tekanan sepanjang permukaan bodi.

2. Distribusi tegangan geser sepanjang permukaan bodi.

\section{Drag Model}

Drag modelmemilikibanyak sekali bentuk danvariasinya.Karakteristik untuk setiap bentuk drag modeljuga tidak sama. Berikutadalahbeberapa bentuk drag model yangsecaraumum banyakdigunakandi kehidupansehari-hari:

1. Platdatarhorizontaldenganposisisearah aliranudara mempunyaihambatan yang diakibatkanhanya oleh gesekanpada permukaan plat.

2. Piringan bundar (circular disc) dengan posisi normal atau tegak lurus arah aliran udara. Pemisahan aliran terjadi pada tepi piringan. Gejolak aliran (wake) berkembang pada bagian bawah/dalam aliran (down stream) dimana tekanan yang terjadi lebih rendah dari sisi atas/luar aliran.

3. Bola atau silinder (sphereor cylinder); pemisahan aliran tidak terjadi di suatu titik yang tetap. Lokasinya bergantung pada bilangan Reynold. Gejolak aliran dan 
hambatan lebih kecil dari yang terjadi pada piringan bundar.

4. Benda streamline(streamlined body); pemisahan aliran terjadihanya pada ujung aliran. Gejolak yang terbentuk sangat kecil.Hambatanyang diakibatkanoleh tekanansangat kecil tetapi hambatan akibatgesekan(friction)lebihbesardari bola karenaluasan permukaan kontak bendastreamlinedenganaliranlebihbesar.

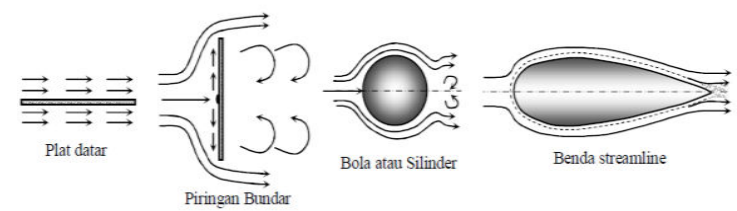

Gambar 1 Aliran Udara yang Melewati Berbagai Obyek Benda

\section{Computational Fluid Dynamics (CFD)}

\section{Computational Fluid Dynamics}

(CFD) adalahmetode penghitungan dengan sebuah controldimensi, luasdan volume dengan memanfaatkan bantuan komputasi computeruntuk melakukanperhitunganpada tiap-tiap elemen pembaginya. Prinsipnya adalahsuaturuang yangberisi fluidayang akan dilakukan penghitungan dibagi-bagi menjadibeberapabagian,hal ini sering disebut denganseldan prosesnyadinamakan meshing.

CFD adalahpenghitunganyang mengkhususkanpada fluida,mulaidarialiran fluida,heattransfer danreaksi kimia yang terjadipadafluida.Atasprinsip-prinsip dasar mekanika fluida, konservasienergi, momentum, massa, penghitungan dengan CFD dapat dilakukan. Secara sederhana prosespenghitunganyang dilakukanoleh
aplikasiCFD adalahdengankontrol-kontrol penghitunganyang telah dilakukanmaka controlpenghitungantersebutakan dilibatkan dengan memanfaatkan persamaan-persamaan yang terlibat.Beberapacontohsoftwareyang sering dipakaiuntuk melakukansimulasidan analisaCFDantaralainCFDSOF,ANSYS,

SolidWork Flow Simulation, Fluent Flowizard, Rhinocheros,dan CATIA.

\section{METODOLOGI PENELITIAN}

\section{Software yang Digunakan dalam Penelitian}

1. AutoCAD 2012

AutoCAD adalah perangkat lunak komputerCADuntukmenggambar2dimensid an3 dimensiyang dikembangkan oleh Autodesk. Keluarga produk AutoCAD, secarakeseluruhan, adalahsoftwareCADyangpalingbanyak digunakandidunia.AutoCAD digunakan oleh insinyursipil, land developers, arsitek, insinyurmesin,desainer interior dan lainlain.

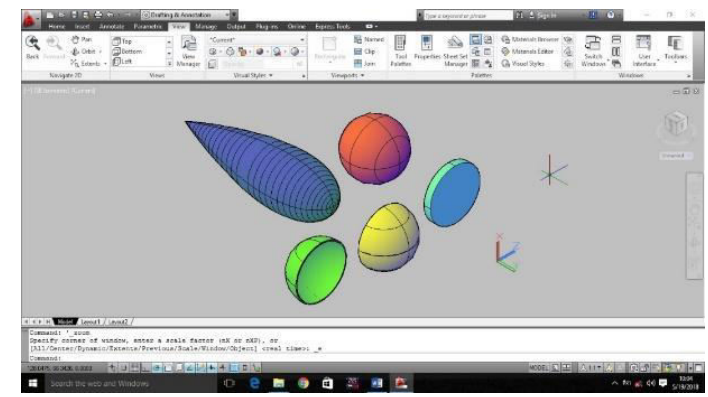

Gambar 2 Tampilan AutoCAD2012

\section{Fluent Flowizard 2.0 .4}

Fluent Flowizard 2.0.4 digunakan untuk melakukanperhitungankomputasi dinamikafluida (CFD)dengancara mengimportgeometrimodeldalambentuk 
fileformat ACIS, mendiskripsikan kondisi fisik darimodel,menentukandaerahdan arah aliran fluida,sertamenentukan parameterparametersolusi. Fluent Flowizard 2.0.4menghasilkanberbagai macam bentuksimulasidiantaranya distribusi tekanan statis,distribusi tekanan totaldan distribusikecepatan.

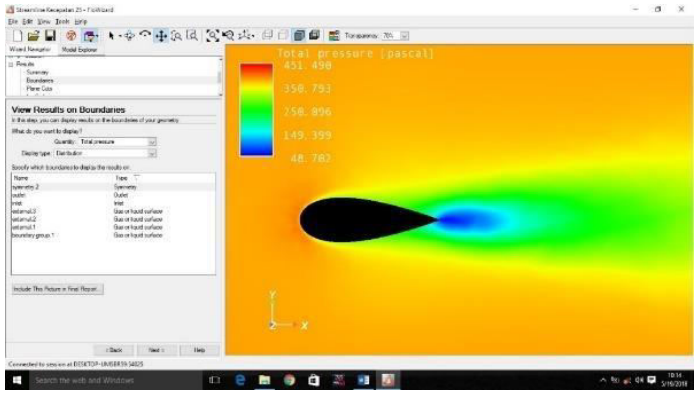

Gambar 3. Tampilan Fluent Flowizard 2.0.4

\section{Prosedur Simulasi}

1. Lakukan pengukuran dimensi drag model.

2. Buat model sesuai dengan ukuran menggunakan software AutoCAD

3. Kemudian Export model tersebut dalam format ACIS (.sat).

4. Buka Aplikasi Fluent FloWizard 2.0.4

5. Tentukan satuan yang akan digunakan dalam software.

6. Import file dengan format ACIS yang telah dibuat di AutoCAD. Tentukan juga ukuran yang digunakan.

7. Tentukan apakah model yang akan disimulasikan tersebut simetri atau tidak.

8. Pilihgeometriyangdigunakanadalah sebuahbentuksolid model.

9. Tentukan aliran yang digunakan adalah aliran luar (External flow).

10.Buat daerah aliran fluida yang melintasi solid model.
11.Lewati langkah untuk menentukan temperaturekarena di dalam simulasi ini temperaturediabaikan.

12.Tentukan jenis aliran yang terjadi dalam fluida yaitu aliran turbulent.

13.Definisikan kondisi fisik daerah aliran, yaitu berupa aliran udara.

14.Tentukan batasan-batasan daerah aliran fluida. Kondisi awal dan akhir dari fluida harus didefinisikan, seperti jenis fluida dan kecepatan aliranya.

15.Tentukan akurasi dan kecepatan dari simulasi. Disini digunakan dengan akurasi dan kecepatan standard.

16.Jika semua masukan sudah benar, maka software akan menunjukkan pemberitahuan bahwa tidak ada eror dalam masukan data.

17.Setting untuk peformansi kalkulasi dari simulasi. Disini digunakan setting standard.

18.Tunggu proses simulasi. Waktu simulasi dipengaruhi oleh model yang digunakan.

19.Hasil simulasi dapat dilihat sesuai apa yang diinginkan, seperti distribusi tekanan statis, distribusi tekanan total maupun distribusi kecepatan. 


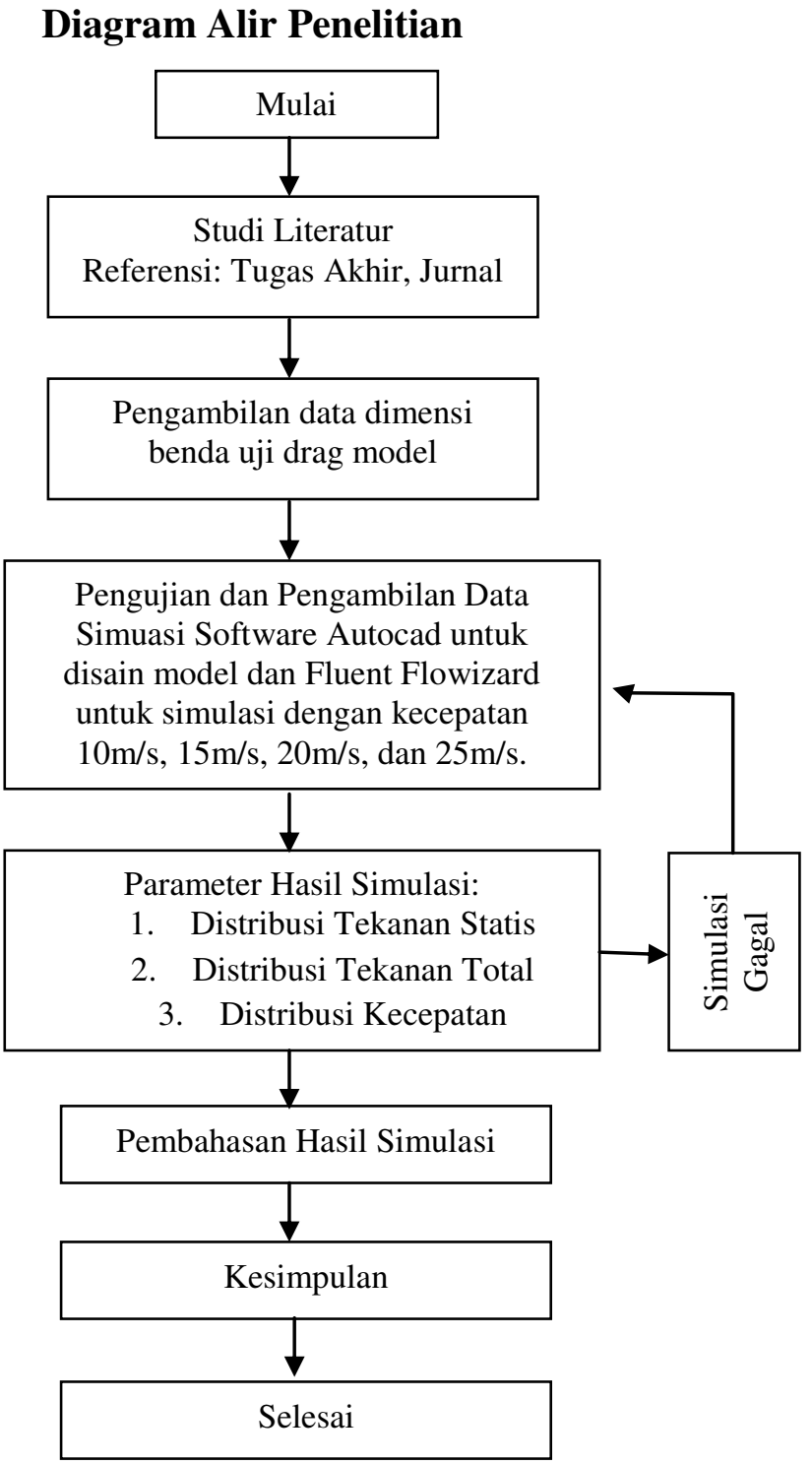

Gambar 4. Diagram Alir Penelitian

\section{HASIL DAN PEMBAHASAN}

Distribusi Tekanan Statis

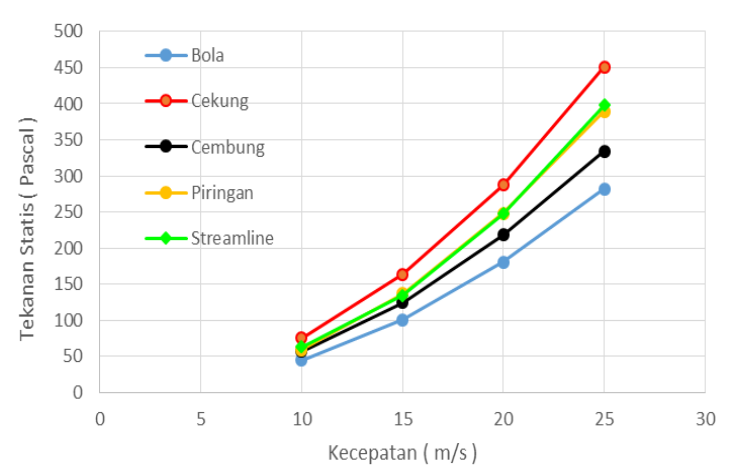

Gambar5 Tekanan Statis dengan Variasi Kecepatan Aliran Fluida dan Drag Model

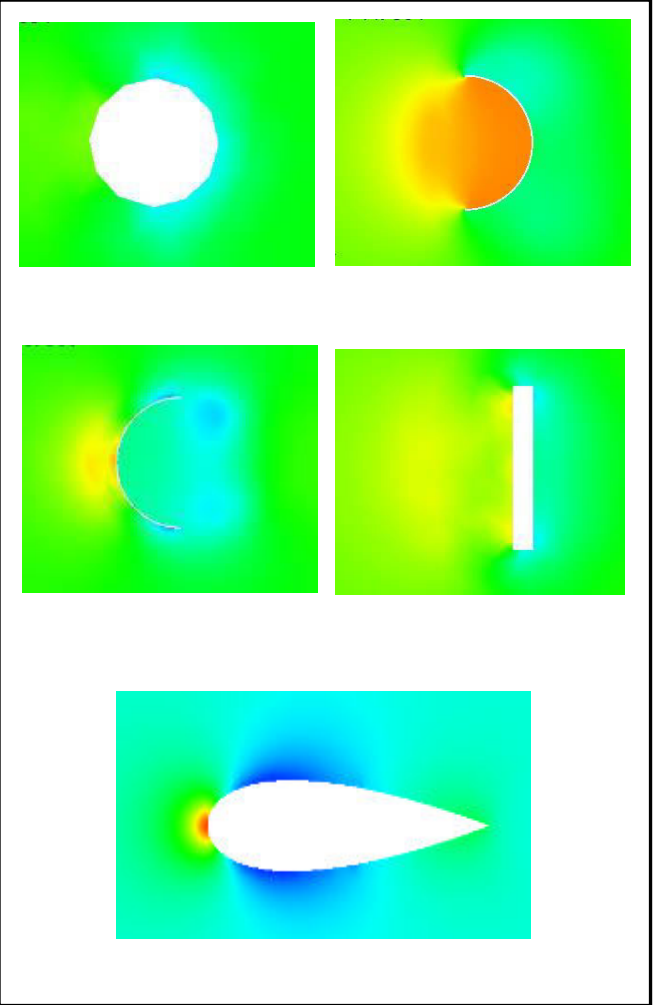

Gambar 6. DistribusiTekananStatis Dengan Variasi Drag Model pada Kecepatan 25 m/s

Jika dilihat pada grafik tersebut terlihat bahwa setiap kenaikan kecepatan aliran fluida maka tekanan statis maksimal yang terjadi akan selalu meningkat. Hal tersebut karenakecepatan merupakan fungsi dari tekanan, sesuai dengan persamaan berikut.

$$
P=\frac{1}{2} \cdot \rho \cdot v^{2}
$$

Dimana setiap kenaikan nilai kecepatan (v) maka akan berdampak pada naiknya nilai tekanan $(\mathrm{P})$. Tekanan statis setiap bentuk drag model pada kondisi kecepatan aliran fluida yang sama maka terlihat bentuk cekung menghasilkan tekanan statis yang paling besar. Nilai tekanan statis yang paling besar terjadi pada saat kecepatan fluida $25 \mathrm{~m} / \mathrm{s}$ dengan besar mencapai 451 pascal yang berada di dalam area cekungnya. Pada 
kecepatan aliran yang sama $25 \mathrm{~m} / \mathrm{s}$ pada bentuk drag model yang lain, tekanan statis maksimal pada bola adalah 282 pascal, cembung adalah 334 pascal, piringan adalah 389 pascal dan streamline adalah 398 pascal. Untuk tekanan terendah terjadi pada bentuk piringan di kecepatan aliran fluida $25 \mathrm{~m} / \mathrm{s}$ dengan besar -509 pascal yang terjadi di bagian ujung permukaan bagian belakang dari bentuk piringan. Untuk tekanan terendah terjadi pada bentuk piringan di kecepatan aliran fluida $25 \mathrm{~m} / \mathrm{s}$ dengan besar -509 pascal yang terjadi di bagian ujung permukaan bagian belakang dari bentuk piringan.

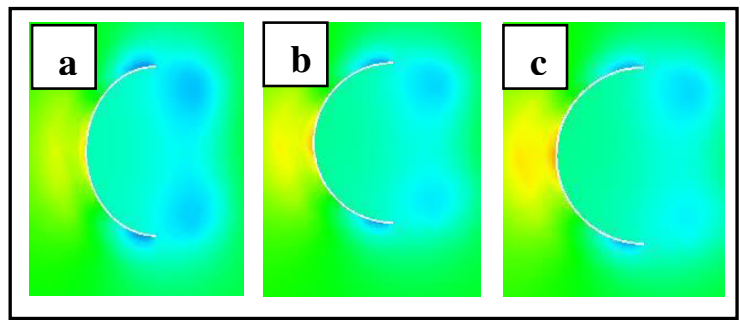

Gambar 6 PerubahanTekanan

StatispadaPermukaanDrag

ModelCembung pada Kecepatan (a) 10 $\mathrm{m} / \mathrm{s}$, (b) $20 \mathrm{~m} / \mathrm{s}$, (c) $25 \mathrm{~m} / \mathrm{s}$

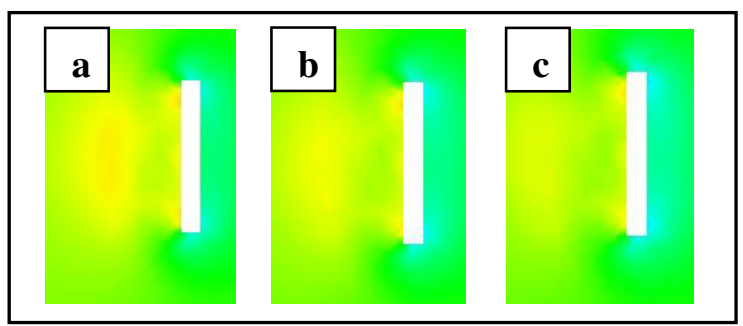

Gambar 7Perubahan Tekanan Statis pada Permukaan Drag Model Piringan pada Kecepatan (a) $10 \mathrm{~m} / \mathrm{s}$, (b) $20 \mathrm{~m} / \mathrm{s}$, (c) $25 \mathrm{~m} / \mathrm{s}$

Jika ditinjau dari pola distribusi tekanan statisnya untuk setiap kenaikan aliran fluida maka 2 bentuk dragmodel yaitu bola dan streamline menunjukkan konsistensi. Dimana pada kedua bentuk tersebut hampir tidak ada perubahan dari bentuk distribusi tekanan statisnya. Sedangkan pada bentuk yang lain ada beberapa perubahan, meskipun tidak terlalu signifikan. Pada bentuk setengah bola cekung perubahan terjadi di area belakang drag model dimana untuk setiap kenaikan kecepatan, maka tekana rendahnya akan semakin banyak. Berbeda dengan bentuk setengah bola cembung dimana untuk setiap kenaikan kecepatan aliran fluida justru area tekanan rendahnya akan semakin merata. Sedangkan pada bentuk piringan, untuk setiap kenaikan kecepatan maka area tekanan tingginya akan semakin berkurang dan area tekanan rendah di area belakang drag model akan lebih banyak, meskipun tidak signifikan.

\section{Distribusi Tekanan Total}

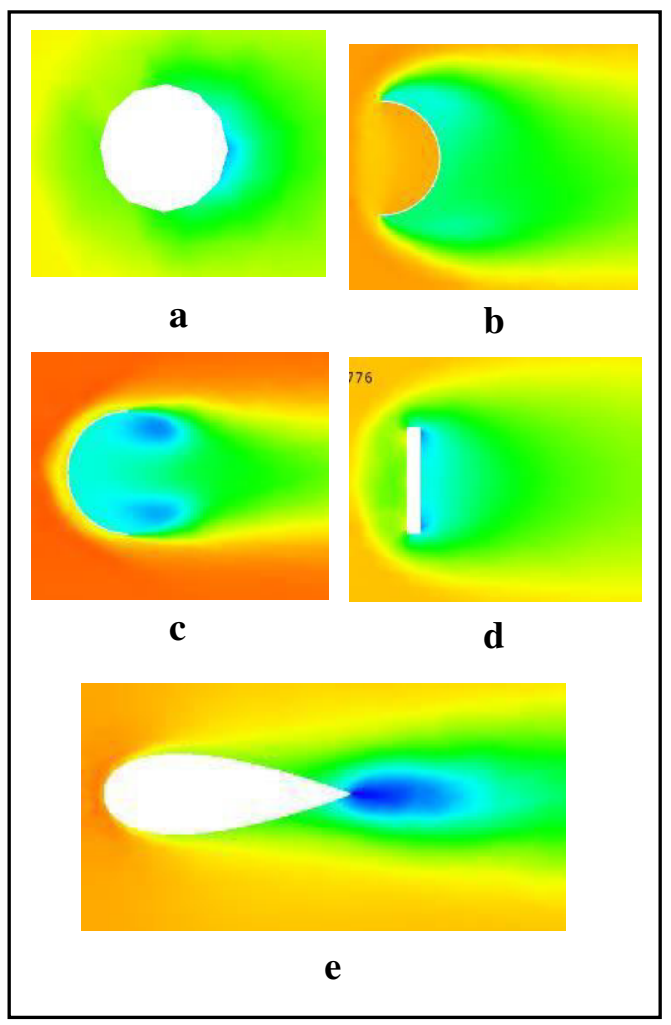

Gambar 8 Distribusi Tekanan Drag Model dengan Kecepatan $25 \mathrm{~m} / \mathrm{s}$ pada Bentuk (a) 


\section{Bola, (b) Cekung, (c) Cembung, (d) Piringan, (e) Streamline}

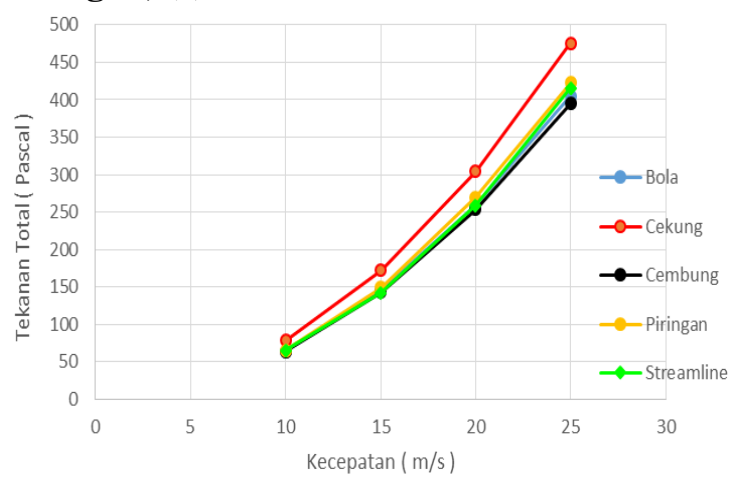

Gambar 9 Tekanan Total dengan

Variasi Kecepatan Aliran Fluida dan Drag Model

Jika dibandingkan distribusi tekanan total maksimalnya setiap bentuk drag model pada kondisi kecepatan aliran fluida yang sama maka terlihat bahwa untuk setiap kenaikan kecepatan aliran fluida maka tekanan totalnya akan semakin meningkat, sama seperti halnya dengan tekanan statisnya. Tekanan total setiap bentuk drag model pada kondisi kecepatan aliran fluida yang sama makaterlihatbentuk cekungmenghasilkan tekanan totalyang paling besar. Nilai tekanan totalyang paling besarterjadipadasaat kecepatanfluida

$25 \mathrm{~m} /$ sdenganbesar

mencapai475pascal.Nilaitekanantotalyang

besarpadabentuk cekung danmerata pada area permukaantersebut berdampak pada gayahambatnyayang secara teorimemang yang paling besardiantara bentuk dragmodel yanglain.Padakecepatanaliranyangsama 25 $\mathrm{m} /$ spadabentukdrag modelyanglain, tekanan totalmaksimalpada bola adalah 405 pascal, cembung adalah395pascal, piringan adalah422 pascaldanstreamlineadalah 416 pascal.Untuk tekananterendahterjadipada bentuk piringandikecepatanaliranfluida $25 \mathrm{~m} / \mathrm{s}$ dengan besar-503 pascal.

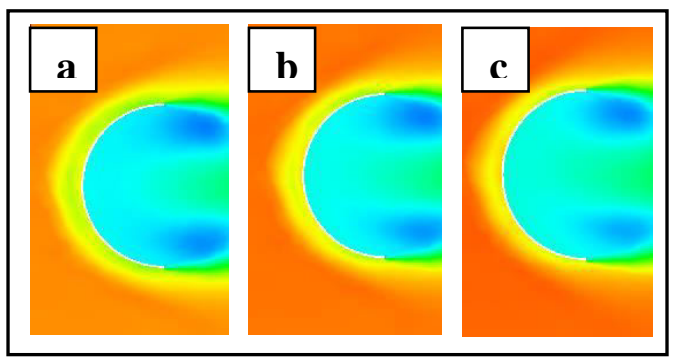

Gambar10 Perubahan pada Bentuk Cembung pada Kecepatan (a) $10 \mathrm{~m} / \mathrm{s}$, (b) 20 $\mathrm{m} / \mathrm{s}$, (c) $25 \mathrm{~m} / \mathrm{s}$

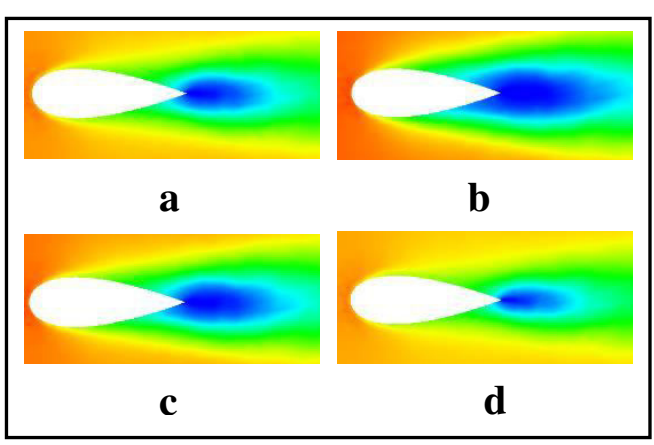

Gambar 11 Perubahan pada Bentuk

Streamline pada Kecepatan (a) $10 \mathrm{~m} / \mathrm{s}$, (b) $15 \mathrm{~m} / \mathrm{s}$, (c) $20 \mathrm{~m} / \mathrm{s}$, (d) $25 \mathrm{~m} / \mathrm{s}$

Jikaditinjaudaripola distribusi tekanan totalnyauntuk setiapkenaikanaliran fluidamakabentuk bola memilikidistribusi tekanan totalpaling konsistendibandingkan denganbentuk yang lainuntuk setiap perubahankecepatanaliranfluida.Sedangkan dragmodelpaling fluktuatifuntuk setiap kecepatanaliran fluidanyaadalah bentuk streamline.Bentuk dragmodelstreamline hamper selalu menunjukkanperubahan distribusitekanantotalyangsangatsiginifikan untuksetiap kenaikan kecepatanaliran fluida. Padabentuk bola, lapisanbatasnyatidak terlalukelihatan,hanyaseparasiwarna saja yang terlihatdiareasekitarnya.Padakeempatbentuk lainlapisanbatasnyasangat terlihat jelas.Lapisanbataspadabentuk cekung 
danpiringancenderung

permukaandaribodydrag

model,sedangkan

padabentuk cembung danstreamline lapisan batasnya beradadekatdengan permukaannya. Setiap kenaikan kecepatan aliran fluida lapisanbataspadacembung akansemakin mendekatidariujung permukaandandiarea belakangnyabentuk lapisanbatasnyaakan semakinmengerucut mendekati drag model. Untuk areadengantekananrendahterlihat jelasyangpaling besaradalahpadabentuk cembung danstreamline. Perbedaan dari keduanyaadalahletak danbesarnyaarea tekananyang cenderung konstan padabentuk cembung sedangkanpadabentuk streamline sangatberubah-ubahuntuk setiapkenaikan kecepatan aliranfluida.

\section{Distribusi Kecepatan}

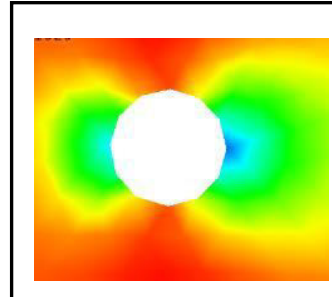

$\mathbf{a}$

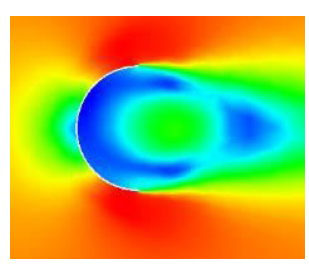

c

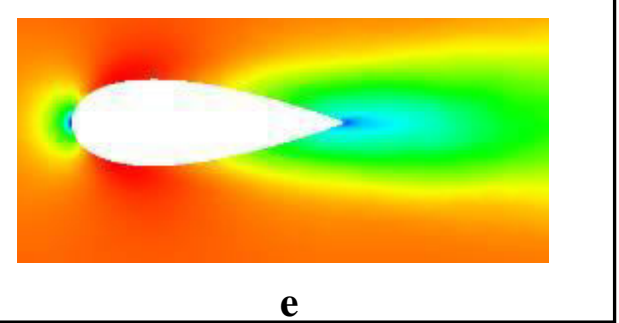

Gambar12 Distribusi Kecepatan Drag

Model dengan Kecepatan $25 \mathrm{~m} / \mathrm{s}$ pada Bentuk (a) Bola, (b) Cekung, (c)

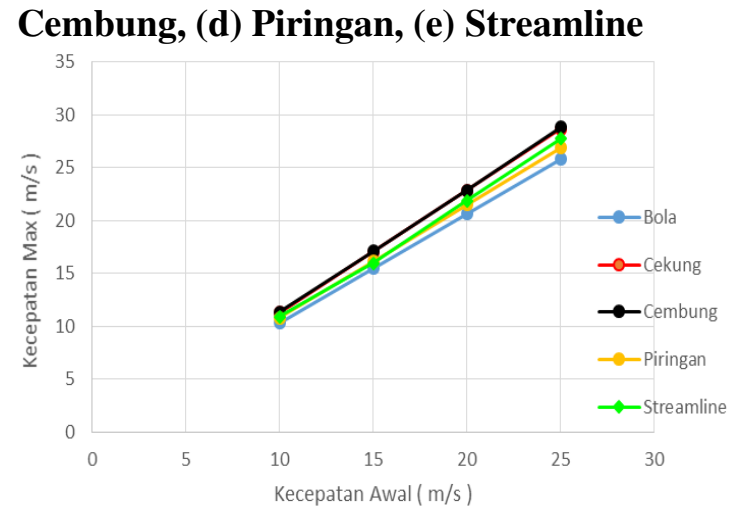

Gambar13KecepatanMaksimal pada

Permukaan Benda denganKecepatan

Aliran FludaMasukdanDragModel

Jika dibandingkan distribusi kecepatansetiapbentuk dragmodelpada kondisikecepatanaliran fluidayang sama maka terlihat bahwa bentuk cembung dan cekung memilikipeningkatan kecepatan terbesardibandingkandenganbentuk yang lain.Bentuk dragmodeldenganpeningkatan kecepatanterendahadalahbentuk bola. Peningkatanterbesar terjadipadabentuk cembung dengankecepatanawal $25 \mathrm{~m} / \mathrm{s}$ dimana terjadipeningkatan kecepatan sebesar3,8

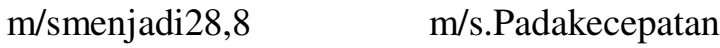
aliranyangsama $25 \mathrm{~m} / \mathrm{spadabentuk} \quad \mathrm{drag}$ modelyang lain, kecepatanmaksimalpada bola adalah $25,8 \mathrm{~m} /$ smeningkat 0,8 dari kecepatan awal, cekung adalah28,7 m/s meningkat3,7 darikecepatan awal,piringan adalah26,9 $\mathrm{m} /$ smeningkat 1,9 $\mathrm{m} / \mathrm{sdan}$ streamlineadalah $27,7 \mathrm{~m} / \mathrm{smeningkat} 2,7 \mathrm{~m} / \mathrm{s}$. 


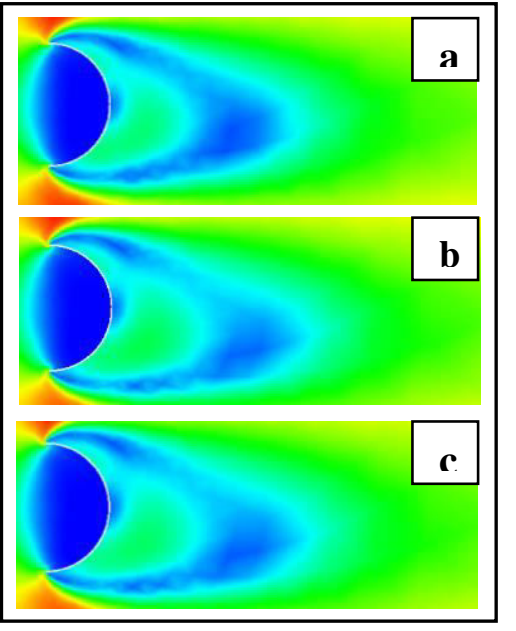

\section{Gambar 14 Perubahan pada bentuk Cekung dengan Kecepatan (a) $10 \mathrm{~m} / \mathrm{s}$, (b) $15 \mathrm{~m} / \mathrm{s}$,} (c) $25 \mathrm{~m} / \mathrm{s}$

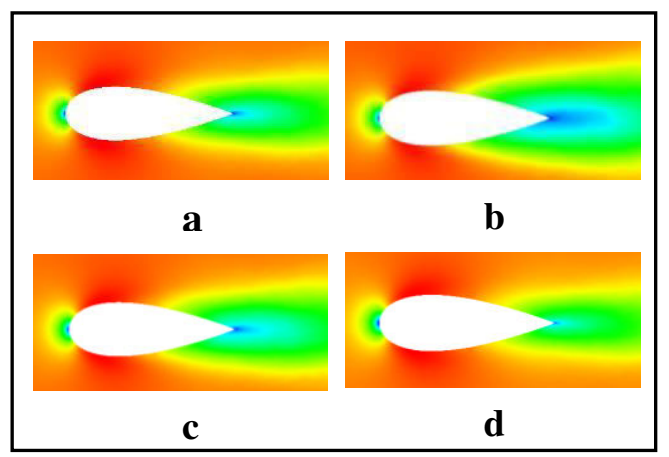

Gambar 15Perubahan pada Bentuk Streamline pada Kecepatan (a) $10 \mathrm{~m} / \mathrm{s}$, (b) $15 \mathrm{~m} / \mathrm{s}$, (c) $20 \mathrm{~m} / \mathrm{s}$, (e) $25 \mathrm{~m} / \mathrm{s}$

Untuk setiapkenaikkankecepatan aliranfluida,3bentuk dragmodelyaitubola, setengahbolacembung danpiringan menunjukkanpola aliranyangkonsistentidak adasuatu perubahanyangbesar terjadi. Sedangkan padabentuksetengah bola cekung danstreamlineperubahan yang terjadiuntuk setiap kenaikkankecepatan aliranadalahpola distribusi tekanan rendahnyadiareabelakang body.Drag modelyangmemilikidaerah dengankecepatan rendahpaling banyak adalahpada bentuk setengahbola cekung, setengahbolacembung danpiringan.
Sedangkanpadabentuk boladanstreamline area dengankecepatan rendahnyatergolong sedikit,hanyasebatasdidekatujung depan danbelakangbentukdragmodel.Padabentuk streamline kembalimenunjukkanpola distribusikecepatanyang sangatberubahubahuntuk setiapperubahankecepatanaliran fluida, sama sepertihalnya dengan distribusi tekanantotalnya.Hal tersebutmenunjukkan bahwapolaalirantekanandankecepatanpada bentuk streamline inisangatdipengaruhioleh kecepatan aliranfluida.

\section{SIMPULAN}

Simpulan yang dapat diambil dari penelitian yang telah dilakukan dengan metode simulasi menggunakan software Fluent Flowizard 2.0.4 adalah sebagai berikut:

1. Untuk setiap kenaikan kecepatan aliran fluida pada semua bentuk drag model maka tekanan statis dan tekanan total maksimalnya akan meningkat

2. Tekanan statis tertinggi terjadi pada bentuk setengah bola cekung saat kecepatan aliran $25 \mathrm{~m} / \mathrm{s}$ dengan besar tekanan statisnya 451 pascal yang berada di depan cekungan.

3. Tekanan total tertinggi terjadi pada bentuk cekung saat kecepatan aliran $25 \mathrm{~m} / \mathrm{s}$ dengan besar tekanan totalnya 475 pascal yang berada di depan cekungan.

4. Untuk setiap kenaikan kecepatan aliran fluida pada semua bentuk drag model maka terjadi peningkatan kecepatan aliran fluida di sekitar tepi samping permukaan drag model.

5. Peningkatan kecepatan tertinggi terjadi pada bentuk setengah bola cembung pada 
kecepatan $25 \mathrm{~m} / \mathrm{s}$ dimana kecepatanya menjadi $28,8 \mathrm{~m} / \mathrm{s}$ atau meningkat $3,8 \mathrm{~m} / \mathrm{s}$ dari kecepatan awal.

\section{DAFTAR PUSTAKA}

Anderson John D, Fundamentals of Aerodynamics (5th ed.), McGrawHill, 2011

Djojodihardjo Harijono, Mekanika Fluida, Erlangga Jakarta, 1983

Dugdale RH, Mekanika Fluida, Erlangga Jakarta, 1986

Houghton EL, PW Carpenter, Aerodynamics for Engineering Students (5th ed.), Butterworth-Heinemann, 2003

Munson Bruce R, Young Donald F, Okhisi Theodore H, Mekanika Fluida, Erlangga Jakarta, 2002

Streeter Victor L, E Benjamin Wylie, Mekanika Fluida, Erlangga Jakarta, 1996

White Frank M, Mekanika Fluida, Erlangga Jakarta, 1988

Fluent Inc, FloWizard 2.0 User's Guide, 2005

Prakoso Verdinand Hadi, Distribusi Tekanan dan Kecepatan pada Airfoil NACA0015 Dengan Variasi Sudut Serang dan Sudut Flap Menggunakan Fluent Flowizard 2.0.4, Teknik Mesin Universitas Merdeka Malang, 2016

Salam H. Nasaruddin, Muh. Noor Umar, Ibnu Sidig, Analisis Eksperimental dan Simulasi Numerik Karaktristik Aliran Fluida Melalui Silinder Persegi dan Segitiga, Teknik Mesin Universitas Hasanuddin, 2013

Yamin Muh., Suhandono, Analisis Aerodinamika Deflektor Pada Truck Menggunakan Software Berbasis Computional Fluid Dynamics (CFD), Teknik Mesin Universitas Gunadarma, 2016 